\title{
Respon Pertumbuhan Tanaman Terong Ungu terhadap Limbah Pupuk Cair Organik dari Rebusan Kedelai (Solanum melongena L.)
}

\author{
Desri Wulandari ${ }^{1}$, Anastasia H.I Sabaruji ${ }^{1}$, Carko $^{2}$, Djaka Mastuti ${ }^{2}$ Latarus Fangohoi $^{*}$ \\ ${ }^{1}$ Program Studi Penyuluhan Pertanian Berkelanjutan, Jurusan Pertanian, Politeknik Pembangunan \\ Pertanian Manokwari \\ ${ }^{2}$ Penyuluh Pertanian Distrik Prafi \\ *Corresponding author: latarus@polbangtanmanokwari.ac.id
}

\begin{abstract}
Abstrak
Penelitian ini bertujuan untuk mengetahui aplikasi pupuk organik cair dari air rebusan kedelai terhadap pertumbuhan tanaman terong ungu umur 10, 20, 30 dan 40 hari. Penelitian ini menggunakan Rancangan Acak Kelompok (RAK) dengan menggunakan 150 tanaman terong ungu yang dibagi menjadi 5 perlakuan dan 5 ulangan yaitu $\mathrm{PO}=$ Tanpa pupuk organik cair (kontrol), $\mathrm{P} 1=$ pupuk organik cair $125 \mathrm{ml}+1,875$ air, $\mathrm{P} 2=$ pupuk organik cair $250 \mathrm{ml}+1.750$ air, $\mathrm{P} 3=$ pupuk organik cair $375 \mathrm{ml}+1.625$ air dan $\mathrm{P} 4=$ =pupuk organik cair $500 \mathrm{ml}+1.500 \mathrm{ml}$ air. Parameter yang diamati adalah tinggi tanaman, jumlah daun dan kuncup bunga. Data dianalisis menggunakan analisis varians (ANOVA) dan selanjutnya diuji menggunakan Uji Jarak Berganda Duncan (DMRT). Berdasarkan hasil penelitian bahwa perlakuan terbaik adalah P4 (500 ml pupuk organik cair dari air rebusan kedelai $+1.500 \mathrm{ml}$ air).
\end{abstract}

Kata kunci: Air rebusan kedelai, Limbah, Solanum melongena L., Terong ungu

\begin{abstract}
This study aims to determine the aplication of liquid organic fertilizer from soybean boiled water to the growth of purple eggplant plants from the age 10,20,30 and 40 days. This study used a Randomized Block Design (RAK) using 150 purple eggpalnt plants devided into 5 treatments and 5 replication, namely $P O=$ Without liquid organic fertilizer (control), $P I=$ liquid organic fertilizer $125 \mathrm{ml}+1.875$ water, $P 2=$ liquid organic fertilizer $250 \mathrm{ml}+1.750$ water, $P 3=$ liquid organic fertilizer $375 \mathrm{ml}+1.625$ water and $P 4=$ liquid organic fertilizer $500 \mathrm{ml}+1.500 \mathrm{ml}$ water. Parameters observed were plant height, number of leaves and flowers buds. The data were analyzed using analysis of variance (ANOVA) and further tested using the Duncan Multiple Range Test (DMRT). Show that the best treatment is obtained from P4 $(500 \mathrm{ml}$ of liquid organic fertilizer from soybean boiled water $+1.500 \mathrm{ml}$ of water $)$.
\end{abstract}

Keywords: Purple eggplant, Solanum melongena L., Soybean cooking water, Waste 
Prosiding Seminar Nasional Pembangunan dan Pendidikan Vokasi Pertanian

Politeknik Pembangunan Pertanian Manokwari, 31 Juli 2021

e ISSN : 2774-1982

DOI : https://doi.org/10.47687/snppvp.v2i1.201

\section{PENDAHULUAN}

Terong (Solanum melongena L.) merupakan jenis sayuran yang sangat populer dan disukai oleh banyak orang karena rasanya enak khususnya diijadikan bahan sayuran atau lalapan. Terong ungu juga mengandunng gizi yang cukup tinggi, terutama kandungan vitamin A dan Fosfor. Menurut Sunarjono (2013), bahwa setiap $100 \mathrm{~g}$ bahan mentah terong mengandung 26 kalori, $1 \mathrm{~g}$ protein, 0,2 g hidrat arang, $25 \mathrm{IU}$ vitamin A, 0,04 g vitamin B dan $5 \mathrm{~g}$ vitamin $\mathrm{C}$. Buah terong ungu memiliki khasiat sebagai obat karena mengandung alkoloid, solanin dan solasodin. Menurut Iritani (2012), menyebutkan bahwa terong memiliki zat anti kanker, kandungan tripsin (protase) yang tergantung pada inhibitor yang dapat melawan zat pemicu kanker.

Proses produksi tempe menghasilkan limbah terutama pada proses pemasakan kacang kedelai. Menurut Nur (2014) diperkirakan untuk skala industri rumah tangga limbah cair yang dihasilkan pada produksi tempe sekitar 200 - 300 liter perhari dari pengolahan $300 \mathrm{~kg}$ kacang kedelai. Air hasil rebusan kacang kedelai yang merupakan limbah pembuatan tempe masih mengandung protein sebesar 5,29\%, lemak sebesar 0,54\%, air sebesar 72,08\%, abu sebesar 3,38\% dan beberapa mineral lain (Wulan, 2014).

Berdasarkan permasalahan limbah yang dihasilkan pada produksi tempe maka diperlukan adanya penanganan khusus untuk mengatasi limbah air rebusan kedelai, salah satu cara untuk meminimalisirkan limbah produksi tempe adalah dengan memanfaatkannya sebagai pupuk organik cair. Bahan yang digunakan untuk pembuatan pupuk organik cair adalah EM4 dan gula pasir. EM4 merupakan kultur campuran dari mikroorganisme yang digunakan untuk meningkatkan populasi mikroorganisme (Siswati et al., 2009). EM4 ini bertujuan untuk mempercepat proses pembuatan pupuk cair, menetralkan bahan organik, dan meningkatkan kualitas pupuk cair (Noor et al., 2016). Kemudian ada bahan lain yaitu gula pasir atau molase merupakan tambahan sumber karbohidrat pada medium pertumbuhan mikroorganisme (Fifendy et al., 2013).

Industri pembuatan tempe banyak ditemukan di Distrik Prafi. Terdapat 10 industri pembuatan tempe sehingga tentunya banyak limbah cair yang dihasilkan terutama limbah dari air rebusan kedelai. Jika tidak tepat dalam pembuangan limbah tersebut maka akan sangat menganggu lingkungan karena akan menimbulkan bau yang tidak sedap. Dengan permasalahan tersebut maka limbah air rebusan kedelai akan diolah menjadi pupuk organik cair yang bisa digunakan untuk tambahan nutrisi pada tanaman terong ungu. Penelitian 
Prosiding Seminar Nasional Pembangunan dan Pendidikan Vokasi Pertanian

Politeknik Pembangunan Pertanian Manokwari, 31 Juli 2021

e ISSN : 2774-1982

DOI : https://doi.org/10.47687/snppvp.v2i1.201

bertujuan untuk: Mengetahui respon pertumbuhan tanaman terong ungu yang diberi pupuk organik cair limbah air rebusan kedelai.

\section{METODE}

Kegiatan penelitian dilaksanakan selama 40 hari dan kegiatan penyuluhan dilaksanakan di Kelompok Tani Sumber Rezeki 1 Kampung Udapi Hilir, Distrik Prafi, Kabupaten Manokwari, Provinsi Papua Barat. Metode yang digunakan dalam penelitian ini adalah Rancangan Acak Kelompok (RAK) dengan 5 ulangan dengan 5 taraf dosis perlakuan. Perlakuan yang digunakan yaitu sebagai berikut:

1. $\mathrm{P} 0=$ Tanpa pemberian Pupuk Organik Cair.

2. $\mathrm{P} 1=$ Pupuk Organik Cair $125 \mathrm{ml}+1.875 \mathrm{ml}$ air.

3. $\mathrm{P} 2=$ Pupuk Organik Cair $250 \mathrm{ml}+1.750 \mathrm{ml}$ air.

4. $\mathrm{P} 3=$ Pupuk Organik Cair $375 \mathrm{ml}+1.625 \mathrm{ml}$ air.

5. $\mathrm{P} 4=$ Pupuk Organik Cair $500 \mathrm{ml}+1.500 \mathrm{ml}$ air.

\section{Variabel dan Pengukuran}

\section{Tinggi Tanaman $(\mathbf{c m})$}

Tinggi tanaman diukur dengan satuan centimeter $(\mathrm{cm})$, diukur mulai dari pangkal batang sampai titik tumbuh tertinggi dengan menggunakan penggaris besi. Pengamatan dilakukan setiap 10 hari sekali, dimulai pada saat tanaman berumur 10 HST. Pengamatan dilakukan sebanyak 4 kali yaitu pada saat 10, 20, 30, dan 40 HST.

\section{Jumlah Daun (Helai)}

Jumlah daun dihitung dengan menggunakan visual mulai dari daun yang sudah menjadi daun sampai bakal daun yang akan menjadi daun. Pengamatan dilakukan setiap 10 hari sekali, dimulai pada saat tanaman berumur 10 HST. Pengamatan dilakukan sebanyak 4 kali yaitu pada saat 10, 20, 30 dan 40 HST.

\section{Bakal Bunga}

Bakal bunga dihitung dengan menggunakan visual dengan melihat secara langsung bunga yang keluar. Pengamatan dimulai pada 30 dan 40 HST. Pada saat 10 dan 20 HST bakal bunga belum kelihatan.

\section{HASIL DAN PEMBAHASAN}

Hasil penelitian selama 40 hari mengenai pengaruh pemberian dosis pupuk organik cair limbah air rebusan kedelai terhadap respon pertumbuhan tanaman terong ungu selama 10, 20, 30 dan 40 HST yang meliputi Tinggi tanaman, jumlah daun dan bakal bunga. 
Prosiding Seminar Nasional Pembangunan dan Pendidikan Vokasi Pertanian

Politeknik Pembangunan Pertanian Manokwari, 31 Juli 2021

e ISSN : 2774-1982

DOI : https://doi.org/10.47687/snppvp.v2i1.201

\section{Tinggi Tanaman}

Hasil pengamatan dan sidik ragam tinggi tanaman terong ungu 10, 20, 30, dan 40 HST menunjukkan bahwa, pupuk organik cair limbah air rebusan kedelai berpengaruh nyata terhadap tinggi tanaman terong ungu. Data pertambahan tinggi tanaman dianalisis dapat di lihat pada Tabel 1.

Pada Tabel 1 terlihat bahwa umur 10 HST, 20 HST dan 30 HST perlakuan P0 dan P1 menunjukkan pengaruh yang tidak berbeda nyata, akan tetapi berbeda nyata dan lebih tinggi pada perlakuan P3 dan P4. Pada 30 HST perlakuan P2 tidak berbeda nyata terhadap P0. Kemudian pada saat tanaman mencapai umur 40 HST perlakuan P2 tidak berbeda nyata terhadap perlakuan P3, namun berbeda nyata terhadap perlakuan P4 yaitu dosis $500 \mathrm{ml}$ $\mathrm{POC}+1.500 \mathrm{ml}$ air.

Tabel 1. Rata-Rata Pertambahan Tinggi Tanaman Terong

\begin{tabular}{ccccc}
\hline \multirow{2}{*}{$\mathrm{P}$} & \multicolumn{4}{c}{ Rata-rata } \\
\cline { 2 - 5 } & $10 \mathrm{HST}$ & $20 \mathrm{HST}$ & $30 \mathrm{HST}$ & $40 \mathrm{HST}$ \\
\hline PO & $17.80 \mathrm{~b}$ & $24.27 \mathrm{~b}$ & $33.40 \mathrm{~b}$ & $46.87 \mathrm{c}$ \\
P1 & $22.67 \mathrm{a}$ & $30.80 \mathrm{a}$ & $43.27 \mathrm{a}$ & $57.67 \mathrm{~b}$ \\
P2 & $21.53 \mathrm{a}$ & $28.67 \mathrm{a}$ & $35.53 \mathrm{~b}$ & $53.60 \mathrm{bc}$ \\
P3 & $21.27 \mathrm{a}$ & $29.53 \mathrm{a}$ & $42.53 \mathrm{a}$ & $56.07 \mathrm{bc}$ \\
P4 & $23.53 \mathrm{a}$ & $31.93 \mathrm{a}$ & $45.27 \mathrm{a}$ & $65.00 \mathrm{a}$ \\
\hline
\end{tabular}

Pada uraian diatas ini diduga pada dosis $500 \mathrm{ml}$ mempengaruhi banyaknya jumlah unsur hara yang dapat disediakan didalam tanah mampu diserap oleh tanaman terong ungu dengan baik sehingga memicu pada tinggi tanaman terong ungu. Selain pengaruh pemberian dosis POC ada salah satu hormon yang memicu pertumbuhan tanaman salah satunya adalah auksin, auksin merupakan hormon yang berada pada ujung tanaman dan daun muda. Auksin juga berfungsi untuk mendorong pertumbuhan tanaman dengan cara pemanjangan sel pada akar dan batang. Menurut Handayanto (1998), pemberian bahan organik yang tinggi dapat menambah unsur hara esensial dan juga dapat meningkatkan ketersediaan unsur hara dalam tanah bagi tanaman terutama unsur hara $\mathrm{N}$ yang memiliki fungsi utama untuk perkembangan vegetatif tanaman seperti pertumbuhan tinggi tanaman. Ketersediaan unsur hara berupa nitrogen dalam bentuk ion nitrit dan nitrat tersedia dengan baik dan seimbang serta mudah diserap oleh akar akan mempengaruhi perkembangan sel dalam jaringan tanaman sehingga memacu laju pertumbuhan vegetaatif berupa tinggi tanaman (Fangohoi, 2013). 
Prosiding Seminar Nasional Pembangunan dan Pendidikan Vokasi Pertanian

Politeknik Pembangunan Pertanian Manokwari, 31 Juli 2021

e ISSN : 2774-1982

DOI : https://doi.org/10.47687/snppvp.v2i1.201

\section{Jumlah Daun}

Hasil pengamatan dan sidik ragam jumlah daun terong ungu 10, 20, 30, dan 40 HST menunjukkan bahwa, pupuk organik cair limbah air rebusan kedelai berpengaruh nyata terhadap jumlah daun terong ungu. Data pertambahan jumlah daun dianalisis dapat dilihat pada Tabel 2.

Tabel 2. Rata-Rata Pertambahan Jumlah Daun Tanaman Terong

\begin{tabular}{ccccc}
\hline \multirow{2}{*}{$\mathrm{P}$} & \multicolumn{4}{c}{ Rata-rata } \\
\cline { 2 - 5 } & $10 \mathrm{HST}$ & $20 \mathrm{HST}$ & $30 \mathrm{HST}$ & $40 \mathrm{HST}$ \\
\hline P0 & $5.80 \mathrm{~b}$ & $9.07 \mathrm{c}$ & $10.93 \mathrm{c}$ & $17.53 \mathrm{~b}$ \\
P1 & $7.33 \mathrm{ab}$ & $10.73 \mathrm{~b}$ & $18.67 \mathrm{~b}$ & $24.60 \mathrm{ab}$ \\
P2 & $8.00 \mathrm{ab}$ & $9.20 \mathrm{c}$ & $19.87 \mathrm{~b}$ & $24.27 \mathrm{ab}$ \\
P3 & $7.67 \mathrm{ab}$ & $11.27 \mathrm{ab}$ & $21.20 \mathrm{~b}$ & $25.00 \mathrm{ab}$ \\
P4 & $8.07 \mathrm{a}$ & $12.20 \mathrm{a}$ & $26.67 \mathrm{a}$ & $33.20 \mathrm{a}$ \\
\hline
\end{tabular}

Tabel 2 terlihat pada hari ke 10 HST perlakuan P0 ridak berbeda nyata terhadap perlakuan P1, P2 dan P3, namun berbeda nyata dan lebih banyak pada perlakuan P4. Kemudian pada hari ke 20 HST dan 30 HST P0 dan P1 tidak berbeda nyata sama halnya dengan P2 dan berbeda nyata pada perlakuan P4. Pada saat tanaman umur 40 HST P0 tidak berbeda nyata terhadap P1, P2 dan P3 akan tetapi berbeda nyata pada P4 dengan nilai tertinggi. Hanolo (1997) menyatakan bahwa, unsur hara nitrogen $(\mathrm{N})$ pada pupuk organik memacu pertumbuhan tanaman, karena nitrogen membentuk asam-asam amino menjadi protein. Protein yang terbentuk digunakan untuk membentuk hormon pertumbuhan. Hal ini sejalan dengan pendapat Hanafiah (2005) penggunaan pupuk nitrogen berperan menonjol terhadap bagian vegetatif tanaman (dedaunan dan pucuk). Pemberian POC dengan intensitas penyiraman lebih banyak memiliki pertumbuhan tanaman yang tidak lebih bagus dengan yang diberikan intensitas penyiraman 1 kali sehari dapat membantu pertumbuhan tanaman (Lutfiana et al., 2019). Dengan adanya nitrogen yang dapat mempercepat proses fotosintesis sehingga pembentukan organ daun menjadi lebih cepat. Rahmah et al. (2014) mengatakan bahwa kelimpahan nitrogen juga mendorong pertumbuhan yang cepat termasuk perkembangan daun, batang lebih besar dan berwarna hijau tua serta mendorong pertumbuhan vegetatif di atas tanah.

\section{Jumlah Bakal Bunga}

Hasil pengamatan dan sidik ragam jumlah bakal bunga terong ungu 30 dan 40 HST menunjukkan bahwa, pupuk organik cair limbah air rebusan kedelai berpengaruh nyata 
Prosiding Seminar Nasional Pembangunan dan Pendidikan Vokasi Pertanian Politeknik Pembangunan Pertanian Manokwari, 31 Juli 2021

e ISSN : 2774-1982

DOI : https://doi.org/10.47687/snppvp.v2i1.201

terhadap jumlah bakal bunga terong ungu. Data pertambahan jumlah bakal bunga dianalisis dapat dilihat pada Tabel 3.

Tabel 3. Rata-Rata Pertambahan Jumlah Bakal Bunga Tanaman Terong

\begin{tabular}{ccc}
\hline \multirow{2}{*}{ Perlakuan } & \multicolumn{2}{c}{ Hari Setelah Tanam } \\
\cline { 2 - 3 } & 30 & 40 \\
\hline P0 & 0.00 & $3.13 \mathrm{c}$ \\
P1 & $1.33 \mathrm{~b}$ & $6.60 \mathrm{~b}$ \\
P2 & $1.40 \mathrm{~b}$ & $5.33 \mathrm{bc}$ \\
P3 & $1.93 \mathrm{~b}$ & $7.40 \mathrm{ab}$ \\
P4 & $2.93 \mathrm{a}$ & $9.67 \mathrm{a}$ \\
\hline
\end{tabular}

Pada Tabel 3 terlihat bahwa pada umur 30 HST P0 berbeda nyata dengan nilai 0.00 yang artinya pada hari yang saam tidak ada bakal bunga. Hal ini bisa dipengearuhi oleh tidak tersedianya unsur hara atau hormon perkembangan bunga tanaman terong. Kemudian perlakuan P1 tidak berbeda nyata terhadap perlakuan P2 dan P3, namun sangat berbeda nyata dan nilai yang tinggi pada perlakuan P4. Kemudian pada saat tanaman umur 40 HST perlakuan P0 tidak berbeda nyata terhadap P3. Hal ini bisa dikarenakan pada perlakuan PO yang awalnya tidak ada bunga pada hari ke 40 HST muncul bunga terjadi karena adanya unsur C-organik dari tanah itu sendiri. Selain itu hormone auksin yang berfungsi sebagai pertumbuhan bunga dan buah berlangsung dengan baik, namun auksin dapat menghambat pertumbuhan jika terkena cahaya matahari. Perlakuan P1 dan P3 tidak berbeda nyata akan tetapi sangat berbeda nyata terhadap perlakuan P4 dengan nilai 9,67 bakal bunga. Parameter ini menunjukkan yang paling cepat berbunga pemberian dosis $500 \mathrm{ml}+1.500$ $\mathrm{ml}$ air dan paling lambat pada perlakuan tanpa pupuk, hal ini artinya bahwa respon tanaman dari berbagai dosis pupuk organik cair tergantung dari penggunaan konsentrasi dari dosis pupuk organik cair. Rizqiani et al. (2007) menyatakan bahwa penggunaan konsentrasi pupuk organik cair yang tepat dapat memperbaiki pertumbuhan, mempercepat panen, memperpanjang masa atau umur produksi dan dapat meningkatkan hasil tanaman.

\section{KESIMPULAN}

Berdasarkan hasil kajian penelitian terkait respon pertumbuhan tanaman terong ungu umur 10, 20, 30 dan 40 HST yang diberi perlakuan dosis pupuk organik cair limbah air rebusan kedelai dan kajian penyuluhan dapat disimpulkan bahwa pemberian dosis pupuk organik cair limbah air rebusan kedelai sangat berpengaruh nyata terhadap parameter pengamatan tinggi tanaman, jumlah daun dan jumlah bakal bunga. Respon pertumbuhan tanaman terong ungu sangat nyata dimana setiap 10 hari sekali pengamatan mengalami 
Prosiding Seminar Nasional Pembangunan dan Pendidikan Vokasi Pertanian

Politeknik Pembangunan Pertanian Manokwari, 31 Juli 2021

e ISSN : 2774-1982

DOI : https://doi.org/10.47687/snppvp.v2i1.201

kenaikan nilai rata rata 7 poin yang cukup tinggi. Pemberian dosis POC yang sangat baik pada pemberian dosis $500 \mathrm{ml}+1.500 \mathrm{ml}$ air yang mendapat nilai tinggi tanaman sebesar $65,00 \mathrm{~cm}$, jumlah daun sebanyak 33,20 helai dan jumlah bakal bunga senilai 9,67 buah.

\section{DAFTAR PUSTAKA}

Fifendy, M., Eldini, E., \& Irdawati, I. (2013). Pengaruh Pemanfaatan Molase Terhadap Jumlah Mikroba Dan Ketebalan Nata Pada Teh Kombucha. In Prosiding Semirata FMIPA Universitas Lampung. 67-72.

Hanafiah, K.A. (2005). Dasar-Dasar Ilmu Tanah. Jakarta: Raja Grafindo.

Handayanto, E. (1998). Pengelolaan Kesuburan Tanah. Fakultas Pertanian. Universitas Brawijaya. Malang.

Hanolo, W. (1997). Tanggapan tanaman selada dan sawi terhadap dosis dan cara pemberian pupuk cair stimulan. Jurnal Agrotropika 1.

Hikma, N., A. Muhammad., \& Umrah. (2014). Potensi Limbah Cair Tempe Secara Mikrobiologis Sebagai Alternatif Penghasil Biogas. Kota Palu : Perpustakaan Universitas Tadulako.

Iritani, G. (2012). Vegetable Gardening. Indonesia Tera. Yogyakarta.

Fangohoi, L. (2013). Variasi pemberian Bokashi pada Budidaya Tanaman Sawi Caisim(Brassica juncea L) DI Desa Randuagung KecamatanLawang Kabupaten Malang Propinsi Jawa Timur. 7(1), 17-21. https://polbangtanmanokwari.ac.id/jurnal/media/files/Jurnal_2016_latarus.pdf

Lutfiana, Z., Fangohoi, L., \& Saikhu, M. (2019). Pengaruh Intensitas Penyiraman terhadap Persemaian Cabai Rawit (Capsicum frutescens L.) dengan Media Semai Pelepah Batang Pisang di Kelompok Tani Morgo Utomo Kelurahan Bence Kecamatan Garum, Kabupaten Blitar, Provinsi Jawa Timur. Agrovigor: Jurnal Agroekoteknologi, 12(2), 82-86. https://doi.org/10.21107/agrovigor.v12i2.5605

Rahmah, A, dkk. (2014). Pengaruh Pupuk Organik Cair Berbahan Dasar Limbah Sawi Putih (Brassica chinensis L.) Terhadap Pertumbuhan Tanaman Jagung Manis (Zea mays L. var. Saccharata). Buletin Anatomi dan Fisiologi. Vol. 22, No. 1.

Rizqiani, N., F.A. Erlina \& W.Y. Nasih. (2007). Pengaruh Dosis dan Frekuensi Pemberian Pupuk Organik Cair Terhadap Pertumbuhan dan Hasil Buncis. Jurnal Ilmu Tanah dan Lingkungan VII (1) : 43-45.

Siswati, N. D., Theodorus, H., \& Eko, S.P.W. (2009). Kajian Penambahan Effective Microorganisms (EM4) Pada Proses Dekomposisi Limbah Padat Industri Kertas. Buana Sains, 9(1), 63-68.

Sunarjono. H. (2013). Bertanam 30 Jenis Sayuran. Penebar Swadaya. Jakarta.

Wulan. (2014). Analisis Kandungan Limbah Cair Pabrik Tempe. Semarang : UNDIP. 